\title{
Design for Machining
}

\author{
Jan Mádl \\ Czech Technical University in Prague, Department of Machining, \\ Process Planning and Metrology
}

Concurrent engineering plays an important role in manufacturing. Cooperation among all factors relating to the realisation of products is now necessary. Production costs represent about $40 \%$ of the selling price of products and therefore design for production and for other aspects is very important

Keywords: concurrent engineering, production, machining, design, costs

\section{REFERENCES}

[1] Black, R.: Design and Research. Macmillan Press, London: 1966.

[2] Helgoson, M.: CAD Integrated Control. Linkoping University, Linkoping, 1998.

[3] Boothroyd, G., Knight, W. A.: Fundamentals of Machining and Machine Tools. Marcel Dekker, Inc., New York and Basel, 1989.

[4] Black, R.: Design and Manufacture. Macmillan Pres, Houndmils, Basingstoke, Hampshire RG21 6XS and London, 1996.

[5] Kalpakjian, S.: Manufacturing Engineering and Technology. Addison-Wesley Publishing Company, Reading, Massachusetts, 1995.

[6] Mádl, J., Vrabec, M.: Technologičnost konstrukce z hlediska obrábění, UJEP, UTRV, Ústí nad Labem, CZ, 1980

[7] Mádl, J.: Manufacturing Processes, Management Accounting and Controlling, Manufacturing Technology, Vol. 4, p. 37-39.ISSN 1213-2489 